\title{
Sister acts: coordinating DNA replication and cohesion establishment
}

\author{
Rebecca Sherwood, ${ }^{1}$ Tatsuro S. Takahashi, ${ }^{2,4}$ and Prasad V. Jallepalli ${ }^{1,3}$ \\ ${ }^{1}$ Molecular Biology Program, Memorial Sloan-Kettering Cancer Center, New York, New York 10065, USA; ${ }^{2}$ Department \\ of Biological Science, Graduate School of Science, Osaka University, Toyonaka Osaka 560-0043, Japan
}

The ring-shaped cohesin complex links sister chromatids and plays crucial roles in homologous recombination and mitotic chromosome segregation. In cycling cells, cohesin's ability to generate cohesive linkages is restricted to $\mathrm{S}$ phase and depends on loading and establishment factors that are intimately connected to DNA replication. Here we review how cohesin is regulated by the replication machinery, as well as recent evidence that cohesin itself influences how chromosomes are replicated.

Physical pairing between sister chromatids plays a vital role in the faithful transmission of genetic information during cell division. In eukaryotes, this pairing is mediated primarily by cohesin, a ring-shaped multiprotein complex that appears to catenate DNA molecules by topological means (Nasmyth and Haering 2009). An important feature of cohesin is that its ability to form such linkages is tightly regulated and, under normal conditions, occurs only during $S$ phase, when new sister DNAs are synthesized. In this review, we discuss how DNA replication and cohesion establishment are coordinated, with specific emphasis on how factors at licensed origins and replication forks modify cohesin's architecture and association with chromatin, and how this in turn affects the dynamics of DNA replication. Highlighting the importance of such regulation, germline mutations that compromise cohesin function are responsible for a constellation of human developmental disorders that have been collectively termed "cohesinopathies" (Dorsett 2007; Liu and Krantz 2008).

\section{Cohesin loading prior to $\mathrm{S}$ phase}

Cohesin is a member of a large family of DNA-associated complexes based on SMC (structural maintenance of chromosome) proteins, whose evolutionary emergence predates the trifurcation of eukaryotes, archaea, and prokaryotes $\sim 3.5$ billion years ago (Woese et al. 1990). All SMC proteins use intramolecular coiled-coil interactions

[Keywords: Cohesin; DNA replication; sister chromatid cohesion; chromosome; mitosis; cell cycle]

Corresponding authors.

${ }^{3}$ E-MAIL jallepap@mskcc.org; FAX (212) 717-3627.

${ }^{4}$ E-MAIL tatsuro_takahashi@bio.sci.osaka-u.ac.jp; FAX 81-6-6850-5440. Article is online at http://www.genesdev.org/cgi/doi/10.1101/gad.1976710. to fold on themselves, producing rod-shaped molecules with an ATPase "head" domain and dimerizing "hinge" at either end (Hirano 2006). In the case of cohesin, the ATPase heads of the Smc1-Smc3 heterodimer are bridged by the non-SMC subunit Scc1 to form a closed ring of 45 nm (Haering et al. 2002; Gruber et al. 2003; Arumugam et al. 2006), while a fourth non-SMC subunit (Scc3 in yeast or stromalin antigen isoforms 1 and 2 [SA1 and SA2] in vertebrates) (Losada et al. 2000; Sumara et al. 2000) interacts directly with Scc1. Considerable evidence supports the notion that the cohesin ring holds sister DNAs together topologically (Nasmyth and Haering 2009), with DNA entering the ring via ATP-dependent opening of the Smc1-Smc3 hinge interface (Arumugam et al. 2003; Weitzer et al. 2003; Gruber et al. 2006).

In yeast, a separate complex consisting of the Scc2 and Scc 4 proteins is necessary to load cohesin onto chromatin in G1 phase (Ciosk et al. 2000; Tomonaga et al. 2000; Bernard et al. 2006). Both Scc2 and Scc4 are widely conserved and necessary for cohesin loading in higher eukaryotes that occurs during telophase /Gillespie and Hirano 2004; Rollins et al. 2004; Takahashi et al. 2004; Seitan et al. 2006; Watrin et al. 2006). Notably, the yeast Scc2-Scc4 complex also regulates the deposition of condensin (D'Ambrosio et al. 2008) and the Smc5-Smc6 repair complex at some chromosomal loci (Lindroos et al. 2006), suggesting that it can function generally as an "SMC loader." Whether a similar dependency exists between these complexes in multicellular organisms remains to be determined. Molecularly, all Scc2 orthologs are typified by large arrays of HEAT repeats at their $\mathrm{C}$ termini (Neuwald and Hirano 2000), whereas their N termini show minimal sequence conservation. Somewhat surprisingly, the latter are crucial for Scc4's interaction with Scc2 (Seitan et al. 2006; Takahashi et al. 2008). How the Scc2-Scc4 complex loads cohesin and other proteinaceous rings onto chromatin is currently unclear, but experiments in Xenopus egg extracts indicate that Scc2's HEAT repeats are essential (Takahashi et al. 2008). One attractive hypothesis is that this portion of Scc2 modulates the ATPase activity of the Smc1-Smc3 heads and/or the opening of the hinge region. Of note, HEAT repeats are also present within Pds5, a cohesin-binding partner with complex and paradoxical roles in cohesion establishment and maintenance, as discussed below. 
In metazoans, the Scc2-Scc4 complex also plays a substantial role in gene expression. For instance, the Drosophila Scc2 ortholog Nipped-B influences the transcription of several developmentally important genes, including cut and Ubx (Rollins et al. 1999; Dorsett et al. 2005). Interestingly, cohesin both enhances and represses transcription of distinct sets of Nipped-B targets (Rollins et al. 2004; Horsfield et al. 2007; Gause et al. 2008; Hallson et al. 2008; Pauli et al. 2008; Schuldiner et al. 2008). Based on these complex phenotypes, the Scc2-Scc4 complex has been proposed to load and unload cohesins dynamically in order to regulate transcription (Dorsett 2009). In humans, mutations in the Scc2 ortholog NIPBL give rise to Cornelia de Lange syndrome (CdLS), a hereditary disorder associated with developmental anomalies across multiple organ systems. Moreover, cell lines established from CdLS patients exhibit abnormalities in gene expression that correlate with diminished levels of cohesin binding at transcription start sites of specific promoters (Liu et al. 2009). Subtle but widespread transcriptional changes have also been detected in $\mathrm{Nipbl}^{+/-}$mice, which display gross developmental defects characteristic of CdLS (Kawauchi et al. 2009).

How cohesin itself regulates gene expression has also been clarified recently. In budding yeast, cohesin preferentially accumulates between convergently transcribed genes and limits spreading of silent chromatin (Donze et al. 1999; Lengronne et al. 2004). A similar pattern of cohesin enrichment is also found in fission yeast and is important for proper termination of convergently synthesized mRNAs (Gullerova and Proudfoot 2008). By comparison, the major binding sites of mammalian cohesins overlap strongly with CTCF, a critical trans-acting factor at chromatin insulators and boundary elements (Parelho et al. 2008; Rubio et al. 2008; Stedman et al. 2008; Wendt et al. 2008). Recent chromosome conformation capture (3C) studies suggest that cohesin and CTCF both contribute to the formation of intrachromosomal loops at specific genes, including the imprinted IGF2/H19 region, the interferon- $\gamma$ locus, and the apolipoprotein gene cluster (Hadjur et al. 2009; Mishiro et al. 2009; Nativio et al. 2009). At present, the physiologic relevance of such loops remains poorly understood, as current methods do not allow for their detection and tracking over time in intact cells. Regardless, both cohesin and CTCF associate with their preferred binding sites throughout the cell cycle, including in G1 phase, when sister chromatids are absent. This observation implies that cohesin's role in regulating gene expression is likely to be orthogonal to its function in pairing sister chromatids.

\section{A link between cohesin loading and prereplication complexes (pre-RCs) in vertebrates}

Timed temperature shift experiments in yeast suggest that the Scc2-Scc4 complex becomes dispensable for cohesion as cells enter S phase (Furuya et al. 1998; Ciosk et al. 2000; Bernard et al. 2006; Lengronne et al. 2006). With the caveat that some residual Scc2-Scc4 activity could have escaped these manipulations, one plausible interpretation is that cohesin rings must be loaded onto chromatin by the time DNA replication begins, or else they lose eligibility to pair sister chromatids. Consistent with this view, metazoans have evolved additional mechanisms that sequence cohesin loading upstream of DNA synthesis. In Xenopus egg extracts, loading of the Scc2Scc4 complex onto chromatin itself depends on pre-RCs (Gillespie and Hirano 2004; Takahashi et al. 2004). PreRCs are formed through the sequential assembly of origin recognition complex (ORC), Cdc6, and Cdt1 at future sites of initiation, termed replication origins (Bell and Dutta 2002), and in turn load the Mcm2-7 helicase onto DNA in an inactive form (Randell et al. 2006; Evrin et al. 2009; Remus et al. 2009|. Subsequent activation of the helicase at the G1/S transition requires further steps, including phosphorylation by the S-phase kinase Cdc7 (Masai et al. 2006; Sheu and Stillman 2006) and interaction with Cdc45 and GINS (Gambus et al. 2006; Moyer et al. 2006; Pacek et al. 2006; Aparicio et al. 2009; Ilves et al. 2010). Interestingly, Cdc7 interacts with the Scc2Scc4 complex, and its kinase activity is essential for loading the complex onto chromatin in Xenopus egg extracts (Fig. 1; Takahashi et al. 2008). Because Cdc7 associates with pre-RCs during G1 phase and is crucial for their subsequent activation at the start of $S$ phase, its involvement might be useful in targeting cohesin to sites of imminent replisome assembly, thereby facilitating cohesin's subsequent interaction with fork-associated regulators (see below).

Unlike in Xenopus, the association of budding yeast cohesin with chromatin is not affected when pre-RC

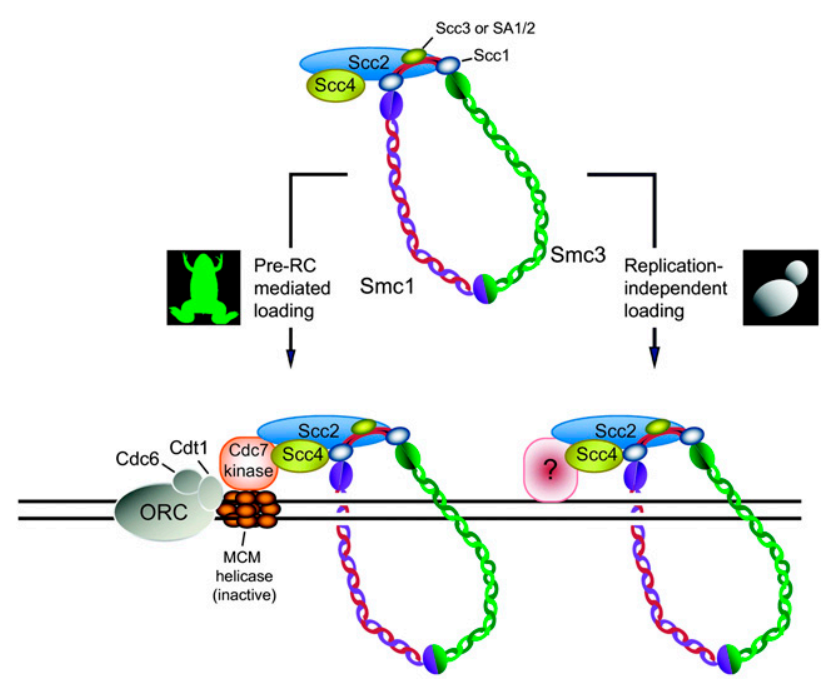

Figure 1. The Scc2-Scc4 cohesin-loading complex is targeted to chromosomes via both replication-dependent and replicationindependent mechanisms. In Xenopus egg extracts, the Scc2Scc4 complex binds chromatin through specific interactions with pre-RCs via the S-phase kinase Cdc7. In contrast, the yeast Scc2-Scc4 complex associates with chromatin and loads cohesin even when pre-RC assembly is prevented. Whether yeast Scc2-Scc4 binds chromosomes directly or through an alternative targeting factor (denoted here by the question mark) is not known. 
assembly is blocked by depleting Cdc6 (Uhlmann and Nasmyth 1998). Conversely, DNA replication is grossly normal when cohesin or the Scc2-Scc4 complex is inactivated (Guacci et al. 1997; Michaelis et al. 1997; Furuya et al. 1998; Ciosk et al. 2000). Thus, the Saccharomyces cerevisiae Scc2-Scc4 complex can be recruited onto chromatin either autonomously or through a replication-independent mechanism. What about the somatic cells of higher eukaryotes? While this issue awaits further investigation, fragments of the human Scc2-Scc4 complex bind chromatin in a Cdc7-dependent manner in Xenopus egg extracts, indicating that such a mechanism is tenable (Takahashi et al. 2008). Equally suggestive is the recent finding that the Drosophila ORC preferentially colocalizes with cohesin, as judged from genome-wide chromatin immunoprecipitation studies (MacAlpine et al. 2010). Nevertheless, whether replication origins (and pre-RCs specifically) regulate cohesin in either flies or mammals remains uncertain. Indeed, as discussed above, cohesin loading is also required to control gene expression, including in terminally differentiated cell types such as neurons (Pauli et al. 2008; Schuldiner et al. 2008). In such compartments, Scc2-Scc4's chromatin association might be dictated by alternative transcription-linked mechanisms, rather than the replicationcoupled pathway operating in early Xenopus embryos, which cycle in the absence of zygotic transcription. Clearly, more work is needed to understand in detail how the Scc2-Scc4 complex is targeted to chromatin and then loads cohesin onto DNA.

\section{Establishing cohesion in S phase via Eco1-mediated acetylation}

The prereplicative loading of cohesin is necessary but not sufficient to ensure that sister chromatids are ultimately linked to one another. Rather, this requires both passage through S phase (Uhlmann and Nasmyth 1998) and the action of so-called cohesion establishment factors. Paramount among these is the Ecol/Ctf7 acetyltransferase (Skibbens et al. 1999; Toth et al. 1999), which is conserved throughout the eukaryotic kingdom (Tanaka et al. 2000; Williams et al. 2003). Vertebrate genomes encode two Eco1 orthologs, called Esco1 and Esco2, that jointly contribute to cohesion (Hou and Zou 2005). Clinically, biallelic mutations in the ESCO2 gene are responsible for Roberts syndrome (RBS), a hereditary developmental disorder typified at the cellular level by weakened centromere cohesion and hypersensitivity to certain genotoxic drugs (e.g., mitomycin C, camptothecin, and etoposide) that target S phase (Vega et al. 2005; van der Lelij et al. 2009).

Early studies in budding and fission yeast demonstrated that Ecol executes its cohesion-promoting role during $S$ phase, but is not required for cohesin loading in G1 phase or maintenance of cohesion in G2 and M phases (Skibbens et al. 1999; Toth et al. 1999; Tanaka et al. 2000), thus distinguishing it from both the Scc2-Scc4 complex and cohesin itself. Subsequent biochemical analysis revealed Ecol to be a highly diverged but bona fide protein acetyltransferase (Ivanov et al. 2002), but how this activity contributes to sister chromatid cohesion remained obscure until recently, when two conserved lysines in Smc3's ATPase domain were found to be Ecol's critical in vivo targets (Rolef Ben-Shahar et al. 2008; Unal et al. 2008; Zhang et al. 2008; Rowland et al. 2009). Acetylation at these sites peaks in $S$ phase and defends cohesin against an "anti-establishment" activity associated with Pds5 and Wapl (Tanaka et al. 2001; Rowland et al. 2009; Sutani et al. 2009), two proteins that interact with cohesin's Scc1 and Scc3 subunits as well as each other (Gandhi et al. 2006; Kueng et al. 2006). A similar regulatory framework also exists in mammals, as depletion of Wapl or Pds5a rescues the phenotypic effects of Esco1 or Esco2 deficiency or mutagenesis of Smc3's acetylation sites in human cells (Gandhi et al. 2006; Terret et al. 2009).

What is the nature of Wapl and Pds5's anti-establishment activity? Previous work uncovered key roles for both proteins in cohesion maintenance, albeit with dramatically different effects, depending on the model system. For example, human Wapl RNAi cells and Xenopus egg extracts depleted of either Wapl or Pds5 fail to remove cohesin from G2 and mitotic chromosomes, resulting in "hypercohesed" sister chromatids that cannot be resolved from one another (Gandhi et al. 2006; Kueng et al. 2006; Shintomi and Hirano 2009). In contrast, yeast wpl1 and pds5 mutants have less (rather than more) cohesin bound to their chromosomes, resulting in subnormal and unstable sister chromatid cohesion (Panizza et al. 2000; Tanaka et al. 2001; Stead et al. 2003; Rowland et al. 2009; Sutani et al. 2009). Mild cohesion defects are also evident in Drosophila wapl mutant embryos (Vernì et al. 2000) and in human cells acutely depleted of Pds5a or Pds5b via RNAi (Losada et al. 2005), but not in $P d s 5 a^{-1-}$ or $P d s 5 b^{-1-}$ mouse embryonic fibroblasts (Zhang et al. 2009), suggesting functional compensation during chronic growth conditions.

One clue for resolving this apparent paradox may reside in the fact that Pds5 itself is a large HEAT repeat protein, akin to the Scc2 subunit of the cohesin loader complex. It is tempting to speculate that the Wapl-Pds5 complex regulates cohesion via a conceptually similar process, involving the stepwise opening and closing of the cohesin ring. If so, then the net effect of Wapl and Pds5 inactivation in a given organism may simply reflect which step of the reaction (ring opening or ring closing) becomes rate-limiting. Regardless, these data also indicate that the anti-establishment activity of the Wapl-Pds5 complex cannot be neatly equated with its effect on cohesion maintenance in G2 or M phase, but might arise only in the specific context of DNA replication. Consistent with this view, recent work indicates that human Wapl and Pds5 slow replication forks unless neutralized by Esco1and Esco2-mediated acetylation, which weakens cohesin's interaction with the Wapl-Pds5 complex (Terret et al. 2009). It remains to be determined if cohesin acetylation has other consequences that are important for establishment, such as a direct effect on cohesin's ability to bind or hydrolyze ATP. Also unclear at the moment is 
the role of sororin, a vertebrate-specific protein that binds to and stabilizes cohesin on chromatin (Rankin et al. 2005; Schmitz et al. 2007). In particular, whether sororin participates directly in cohesion establishment during $S$ phase or simply maintains cohesion post-replicatively remains to be elucidated.

\section{Building cohesion at the replication fork}

Sister chromatid cohesion requires the identification and pairing of two identical copies of each chromosome, rather than two unrelated chromosomes or homologs. A natural context for these transactions exists at the replication fork, which provides a temporary bridge between sister DNAs. Indeed, considerable physical and functional evidence links both Ecol-related acetyltransferases and other cohesion establishment factors to replication forks. For example, early studies indicated that yeast with thermolabile versions of Ecol could be at least partially rescued through overexpression of PCNA (Skibbens et al. 1999), the homotrimeric sliding clamp that tethers DNA polymerases and other replication proteins to the fork (Moldovan et al. 2007). One such factor is Ecol itself, which contains a conserved PCNA-binding motif that is essential for its cohesive activity (Lengronne et al. 2006; Moldovan et al. 2006). Consistently, cohesin acetylation depends on DNA synthesis per se, rather than cell cycle timing (Rolef Ben-Shahar et al. 2008), and, at least in human cells, is supported by the alternative replication factor C-Ctf18 (RFC $\left.{ }^{\mathrm{Ctf1}}{ }^{18}\right)$ complex, which loads PCNA onto forks both in vitro and in vivo (Bermudez et al. 2003; Lengronne et al. 2006; Terret et al. 2009). Finally, multiple components of the replisome progression complex (RPC), which couples the activated form of the Mcm2-7 helicase to the leading and lagging strand machinery (Gambus et al. 2006), are also important for cohesion establishment. This group includes the Ctf4/AND-1 protein, which tethers and activates DNA polymerase $\alpha$ on the lagging strand (Zhu et al. 2007; Gambus et al. 2009; Tanaka et al. 2009; Bermudez et al. 2010); the Mrc1/claspin, Tof1/ timeless, and Csm3/tipin proteins, which stabilize stalled replication forks and transduce checkpoint signals in concert with DNA polymerase $\epsilon$ on the leading strand (Chini and Chen 2003; Katou et al. 2003; Lee et al. 2003; Chou and Elledge 2006; Errico et al. 2007; Unsal-Kacmaz et al. 2007; Yoshizawa-Sugata and Masai 2007; Lou et al. 2008; Leman et al. 2010); and Chl1/CHLR1, a 5'-3' DNA helicase thought to be involved in processing Okazaki fragments (Petronczki et al. 2004; Farina et al. 2008). Recently, biallelic mutations in human CHLR1 were linked to Warsaw breakage syndrome, a rare hereditary disorder associated with both cohesion loss and chromosome breakage (van der Lelij et al. 2010).

The involvement of these replisome-associated factors is especially fascinating in light of current ideas for how replication forks and cohesin rings interact during the establishment process. One proposal is that either replication forks must be smaller than cohesin's central aperture, in which case they could simply slide through the ring, or else cohesin must be transiently enlarged to accommodate the fork without dissociating from chromatin entirely. Based on concepts derived from prokaryotic DNA replication-such as the formation of large DNA loops that enable coordinated leading and lagging strand synthesis (Alberts et al. 1983), efficient recycling of the lagging strand polymerase (Hamdan et al. 2009), and inclusion of a third clamp-polymerase module in the replisome (McInerney et al. 2007; Reyes-Lamothe et al. 2010/—and considering the greater number of fork-associated proteins in eukaryotes (Stillman 2008), eukaryal replisomes may experience significant challenges in traversing cohesin-bound regions of the genome (Fig. 2). Such encounters are expected to affect nearly all replication forks, given the high density of cohesin-binding sites across the genome (approximately one per $20 \mathrm{~kb}$ ) (Parelho et al. 2008; Wendt et al. 2008) as compared with the $\sim 100$ $\mathrm{kb}$ interval between replication origins (Huberman and Riggs 1968). Furthermore, atomic force microscopy and in vivo Förster resonance energy transfer (FRET) experiments suggest that cohesin's coiled coils are remarkably flexible, and that Pds5 contacts not only Scc1, but also the Smc1-Smc3 hinge on the opposite side of the ring (Sakai et al. 2003; Mc Intyre et al. 2007), which would tend to reduce cohesin's cross-sectional area. Smc3 acetylation might be required to counteract this tendency as replisomes pass through the ring, thereby facilitating replication fork progression and sister chromatid entrapment in one step. Once formed, such entrapment may also stabilize replication forks and/or enable sister chromatiddependent restart pathways (Branzei and Foiani 2010).

In addition to the preceding model, other scenarios can be envisioned, whereby cohesin's interaction with

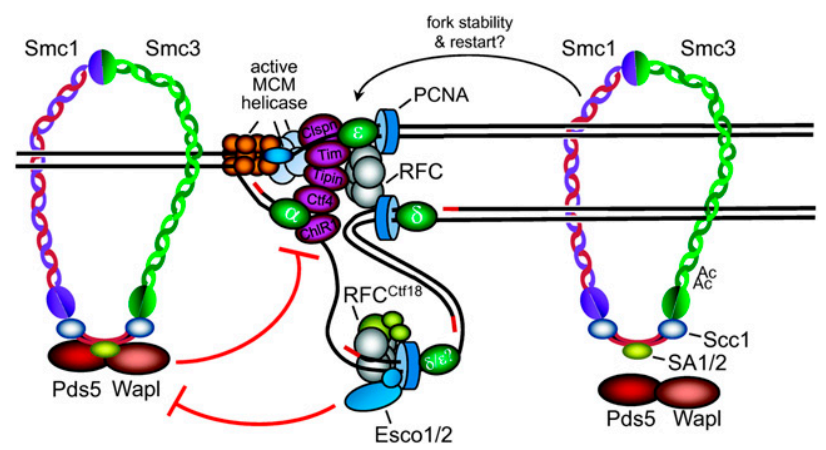

Figure 2. Building cohesion at the replication fork. At S-phase onset, replication forks encounter cohesin rings that are unacetylated and tightly bound to Wapl and Pds5, which antagonize cohesion establishment and replication fork progression. Through recruitment and activation of Ecol-related acetyltransferases, replication forks modify cohesin's Smc3 subunit to weaken its interaction with the Wapl-Pds5 complex. This may put cohesin in an "open" conformation that allows the replication fork to progress while trapping the nascent sister chromatids inside the ring. Alternatively, it is possible that cohesin rings are displaced by advancing replication forks, but then are subjected to a second round of loading behind the fork. However generated, entrapment of the nascent sister DNAs is likely to enhance fork stability by enabling homology-dependent pathways of fork repair and restart. Further discussion of these points can be found in the text. 
unreplicated chromosomes is nontopological or otherwise sensitive to displacement by the replisome, but is then reconstituted (and converted into a topological interaction that catenates both sister DNAs) via a second round of cohesin loading behind the fork (Milutinovich et al. 2007). Attempts to detect such reloading via timed inactivation of the Scc2-Scc4 complex have thus far proven unsuccessful (Lengronne et al. 2006). Nevertheless, it cannot be excluded that such reactions, mediated by trace levels of Scc2-Scc4 activity or an entirely separate cohesin-loading system, still transpired at replication forks. Clearly, more work is needed to understand how cohesin interacts with DNA templates before, during, and after their transit through the replication machinery.

Regardless of whether replication forks slide through or displace and reload cohesin rings, the notion that fork progression itself is tied to cohesin acetylation may shed light on why all known cohesion establishment factors are also implicated in maintaining the processivity and stability of replication forks. For example, the inactivation of RPC components causes significant slowing of replication forks at baseline, as well as high rates of fork collapse in the presence of chemical inhibitors of DNA synthesis (Szyjka et al. 2005; Tourriere et al. 2005; Errico et al. 2007; Unsal-Kacmaz et al. 2007; Petermann et al. 2008; Gambus et al. 2009; Tanaka et al. 2009; Bermudez et al. 2010). Both effects are thought to arise from uncoupling of the replicative helicase from the leading and/ or lagging strand polymerases (Katou et al. 2003; Gambus et al. 2009). One possibility is that these replisome components are needed primarily to recruit or activate Eco1related acetyltransferases and counteract Wapl and Pds5's tendency to uncouple replisomes. This scenario explains the role of the RFC ${ }^{\mathrm{Ctt11}}$ clamp loader in human cells, as its absence causes Smc3 hypoacetylation and a marked decrease in fork speeds that can be reversed by codepleting Pds5a (Terret et al. 2009). Alternatively, replisomes missing these accessory factors might be intrinsically prone to uncoupling regardless of cohesin's acetylation status, in which case ectopic inactivation of Wapl or Pds5 should have little or no ability to restore normal fork speeds or stability. In conclusion, it will be important to understand whether other establishment factors build cohesion primarily by promoting cohesin's timely modification by Eco1-related enzymes, or through collateral activities that impinge directly on leading or lagging strand synthesis.

\section{Relevance of cohesion establishment to human disease}

As noted above, biallelic mutations in the human ESCO2 locus are responsible for RBS. The vast majority of these mutations truncate Esco2 upstream of its C-terminal acetyltransferase domain, while the remainder directly target its enzymatic activity (Gordillo et al. 2008). The manifestations of Esco2 deficiency in RBS patients partially overlap with those of CdLS, as both syndromes are associated with symmetrical limb defects, mental retardation, and delayed intrauterine and postnatal growth (Dorsett 2007; Liu and Krantz 2008). However, a unique and diagnostically important feature of RBS is the presence of centromere cohesion defects, which manifest as a parallel (rather than centrally constricted) configuration of sister chromatids on metaphase spreads (German 1979). Nevertheless, RBS patient cell lines do not accumulate in mitosis (Gordillo et al. 2008), as would be expected if centromere cohesion was weakened to levels that were inadequate to satisfy the spindle assembly checkpoint (Kops et al. 2005). Consequently, it has been proposed that the nonmitotic effects of Esco2 deficiency might be more relevant (Gordillo et al. 2008). Cells from RBS patients exhibit both increased sensitivity to genotoxic drugs that target S phase (van der Lelij et al. 2009) and diminished replication fork speeds, similar to Esco2 RNAi cells (Terret et al. 2009). Could such defects contribute to the pathogenesis of RBS? While a definitive answer will require the generation of Esco2 knockout mice as in vivo models, there are intriguing reasons to think so. DNA replication in metazoan organisms is remarkably plastic, as early embryos activate $\sim 10$ times as many origins as somatic cells, resulting in an average replicon size of $\sim 10 \mathrm{~kb}$ (Arias and Walter 2007). How $90 \%$ of these initially active origins become dormant as development proceeds is a fascinating unsolved problem. Nevertheless, this arrangement provides somatic cells with a crucial defense against stalled or collapsed replication forks, as conditions that slow DNA synthesis rates also trigger the reactivation of dormant origins (Anglana et al. 2003). This shift in replication dynamics is also accompanied by a significant change in nuclear architecture, as chromatin loops (operationally defined by their attachment to an insoluble nuclear scaffold) are reset to a smaller size (Courbet et al. 2008). Conversely, downregulating cohesin increases the size of such loops, while diminishing their density of active replication origins (Guillou et al. 2010). Thus, Esco2 deficiency might cause not only replication stress in developmentally sensitive progenitor cells, but also more sweeping changes in chromosome structure. Regardless of the exact route by which Esco2 sustains embryogenesis, it will be important to know if Esco2-deficient mice develop normally when Wapl, Pds5a, or Pds5b levels are partially reduced, as it would validate these cohesin regulators as pathological effectors and therapeutic targets in human RBS.

\section{Outlook}

Considerable progress has been made toward understanding how sister chromatids become connected to one another during $S$ phase. However, major questions remain about the mechanism of cohesin's initial loading onto chromatin and subsequent entrapment of nascent sister chromatids at replication forks, which have yet to be visualized directly. Doing so will require adaptation of in vitro DNA replication systems, based on DNA tumor viruses or Xenopus egg extracts, to model these reactions in ensemble or single-molecule forms. A clearer view of how cohesin is regulated by post-translational modifications and interactions with its regulatory partners is also needed, which will depend on the systematic 
reconstitution of holo and apo complexes for enzymatic and structural studies. Complementing this effort, it will be useful to determine how the cohesin loading and establishment machinery are directed to chromatin, especially in higher eukaryotes, where cohesin has a prominent noncohesive function in gene expression. Lastly, it will be important to generate accurate models of human cohesinopathies in animals in order to understand how alterations in cohesin regulation give rise to such profound and even life-threatening consequences for the whole organism.

\section{Acknowledgments}

Work in the laboratory of P.V.J. is supported by grants from the National Institutes of Health (GM094972) and the American Cancer Society (CCG114520). T.S.T. is supported by grants from the Ministry of Education, Science, Sports, and Culture of Japan, the Sumitomo Foundation, the Uehara Memorial foundation, and the Naito Foundation.

\section{References}

Alberts BM, Barry J, Bedinger P, Formosa T, Jongeneel CV, Kreuzer KN. 1983. Studies on DNA replication in the bacteriophage T4 in vitro system. Cold Spring Harb Symp Quant Biol 47: 655-668.

Anglana M, Apiou F, Bensimon A, Debatisse M. 2003. Dynamics of DNA replication in mammalian somatic cells: Nucleotide pool modulates origin choice and interorigin spacing. Cell 114: 385-394.

Aparicio T, Guillou E, Coloma J, Montoya G, Mendez J. 2009. The human GINS complex associates with Cdc45 and MCM and is essential for DNA replication. Nucleic Acids Res 37: 2087-2095.

Arias EE, Walter JC. 2007. Strength in numbers: Preventing rereplication via multiple mechanisms in eukaryotic cells. Genes Dev 21: 497-518.

Arumugam P, Gruber S, Tanaka K, Haering CH, Mechtler K, Nasmyth K. 2003. ATP hydrolysis is required for cohesin's association with chromosomes. Curr Biol 13: 1941-1953.

Arumugam P, Nishino T, Haering CH, Gruber S, Nasmyth K. 2006. Cohesin's ATPase activity is stimulated by the C-terminal Winged-Helix domain of its kleisin subunit. Curr Biol 16: 1998-2008.

Bell SP, Dutta A. 2002. DNA replication in eukaryotic cells. Annu Rev Biochem 71: 333-374.

Bermudez V, Maniwa Y, Tappin I, Ozato K, Yokomori K, Hurwitz J. 2003. The alternative Ctf18-Dcc1-Ctf8-replication factor $\mathrm{C}$ complex required for sister chromatid cohesion loads proliferating cell nuclear antigen onto DNA. Proc Natl Acad Sci 100: 10237-10242.

Bermudez VP, Farina A, Tappin I, Hurwitz J. 2010. Influence of the human cohesion establishment factor Ctf4/AND-1 on DNA replication. I Biol Chem 285: 9493-9505.

Bernard P, Drogat J, Maure JF, Dheur S, Vaur S, Genier S, Javerzat JP. 2006. A screen for cohesion mutants uncovers Ssl3, the fission yeast counterpart of the cohesin loading factor Scc4. Curr Biol 16: 875-881.

Branzei D, Foiani M. 2010. Maintaining genome stability at the replication fork. Nat Rev Mol Cell Biol 11: 208-219.

Chini CC, Chen J. 2003. Human claspin is required for replication checkpoint control. J Biol Chem 278: 30057-30062.

Chou DM, Elledge SJ. 2006. Tipin and Timeless form a mutually protective complex required for genotoxic stress resistance and checkpoint function. Proc Natl Acad Sci 103: 1814318147.

Ciosk R, Shirayama M, Shevchenko A, Tanaka T, Toth A, Nasmyth K. 2000. Cohesin's binding to chromosomes depends on a separate complex consisting of Scc2 and Scc4 proteins. Mol Cell 5: 243-254.

Courbet S, Gay S, Arnoult N, Wronka G, Anglana M, Brison O, Debatisse M. 2008. Replication fork movement sets chromatin loop size and origin choice in mammalian cells. Nature 455: 557-560.

D'Ambrosio C, Schmidt CK, Katou Y, Kelly G, Itoh T, Shirahige K, Uhlmann F. 2008. Identification of cis-acting sites for condensin loading onto budding yeast chromosomes. Genes Dev 22: 2215-2227.

Donze D, Adams CR, Rine J, Kamakaka RT. 1999. The boundaries of the silenced HMR domain in Saccharomyces cerevisiae. Genes Dev 13: 698-708.

Dorsett D. 2007. Roles of the sister chromatid cohesion apparatus in gene expression, development, and human syndromes. Chromosoma 116: 1-13.

Dorsett D. 2009. Cohesin, gene expression and development: Lessons from Drosophila. Chromosome Res 17: 185-200.

Dorsett D, Eissenberg JC, Misulovin Z, Martens A, Redding B, McKim K. 2005. Effects of sister chromatid cohesion proteins on cut gene expression during wing development in Drosophila. Development 132: 4743-4753.

Errico A, Costanzo V, Hunt T. 2007. Tipin is required for stalled replication forks to resume DNA replication after removal of aphidicolin in Xenopus egg extracts. Proc Natl Acad Sci 104: 14929-14934.

Evrin C, Clarke P, Zech J, Lurz R, Sun J, Uhle S, Li H, Stillman B, Speck C. 2009. A double-hexameric MCM2-7 complex is loaded onto origin DNA during licensing of eukaryotic DNA replication. Proc Natl Acad Sci 106: 20240-20245.

Farina A, Shin JH, Kim DH, Bermudez VP, Kelman Z, Seo YS, Hurwitz J. 2008. Studies with the human cohesin establishment factor, ChlR1. Association of ChlR1 with Ctf18-RFC and Fen1. J Biol Chem 283: 20925-20936.

Furuya K, Takahashi K, Yanagida M. 1998. Faithful anaphase is ensured by Mis4, a sister chromatid cohesion molecule required in $\mathrm{S}$ phase and not destroyed in G1 phase. Genes Dev 12: 3408-3418.

Gambus A, Jones RC, Sanchez-Diaz A, Kanemaki M, van Deursen F, Edmondson RD, Labib K. 2006. GINS maintains association of Cdc45 with MCM in replisome progression complexes at eukaryotic DNA replication forks. Nat Cell Biol 8: 358-366.

Gambus A, van Deursen F, Polychronopoulos D, Foltman M, Jones RC, Edmondson RD, Calzada A, Labib K. 2009. A key role for Ctf4 in coupling the MCM2-7 helicase to DNA polymerase $\alpha$ within the eukaryotic replisome. EMBO I 28: 2992-3004.

Gandhi R, Gillespie PJ, Hirano T. 2006. Human Wapl is a cohesin-binding protein that promotes sister-chromatid resolution in mitotic prophase. Curr Biol 16: 2406-2417.

Gause M, Webber HA, Misulovin Z, Haller G, Rollins RA, Eissenberg JC, Bickel SE, Dorsett D. 2008. Functional links between Drosophila Nipped-B and cohesin in somatic and meiotic cells. Chromosoma 117: 51-66.

German J. 1979. Roberts' syndrome. I. Cytological evidence for a disturbance in chromatid pairing. Clin Genet 16: 441-447.

Gillespie PJ, Hirano T. 2004. Scc2 couples replication licensing to sister chromatid cohesion in Xenopus egg extracts. Curr Biol 14: 1598-1603.

Gordillo M, Vega H, Trainer AH, Hou F, Sakai N, Luque R, Kayserili H, Basaran S, Skovby F, Hennekam RC, et al. 2008. 
The molecular mechanism underlying Roberts syndrome involves loss of ESCO2 acetyltransferase activity. Hum Mol Genet 17: 2172-2180.

Gruber S, Haering CH, Nasmyth K. 2003. Chromosomal cohesin forms a ring. Cell 112: 765-777.

Gruber S, Arumugam P, Katou Y, Kuglitsch D, Helmhart W, Shirahige K, Nasmyth K. 2006. Evidence that loading of cohesin onto chromosomes involves opening of its SMC hinge. Cell 127: 523-537.

Guacci V, Koshland D, Strunnikov A. 1997. A direct link between sister chromatid cohesion and chromosome condensation revealed through the analysis of MCD1 in S. cerevisiae. Cell 91: $47-57$.

Guillou E, Ibarra A, Coulon V, Casado-Vela J, Rico D, Casal I, Schwob E, Losada A, Mendez J. 2010. Cohesin organizes chromatin loops at DNA replication factories. Genes Dev (this issue). doi: 10.1101/gad.608210.

Gullerova M, Proudfoot NJ. 2008. Cohesin complex promotes transcriptional termination between convergent genes in S. pombe. Cell 132: 983-995.

Hadjur S, Williams LM, Ryan NK, Cobb BS, Sexton T, Fraser P, Fisher AG, Merkenschlager M. 2009. Cohesins form chromosomal cis-interactions at the developmentally regulated IFNG locus. Nature 460: 410-413.

Haering CH, Löwe J, Hochwagen A, Nasmyth K. 2002. Molecular architecture of SMC proteins and the yeast cohesin complex. Mol Cell 9: 773-788.

Hallson G, Syrzycka M, Beck SA, Kennison JA, Dorsett D, Page SL, Hunter SM, Keall R, Warren WD, Brock HW, et al. 2008. The Drosophila cohesin subunit $\operatorname{Rad} 21$ is a trithorax group (trxG) protein. Proc Natl Acad Sci 105: 12405-12410.

Hamdan SM, Loparo JJ, Takahashi M, Richardson CC, van Oijen AM. 2009. Dynamics of DNA replication loops reveal temporal control of lagging-strand synthesis. Nature 457: 336-339.

Hirano T. 2006. At the heart of the chromosome: SMC proteins in action. Nat Rev Mol Cell Biol 7: 311-322.

Horsfield JA, Anagnostou SH, Hu JK, Cho KH, Geisler R, Lieschke G, Crosier KE, Crosier PS. 2007. Cohesin-dependent regulation of Runx genes. Development 134: 26392649.

Hou F, Zou H. 2005. Two human orthologues of Ecol/Ctf7 acetyltransferases are both required for proper sister-chromatid cohesion. Mol Biol Cell 16: 3908-3918.

Huberman JA, Riggs AD. 1968. On the mechanism of DNA replication in mammalian chromosomes. J Mol Biol 32: 327341.

Ilves I, Petojevic T, Pesavento JJ, Botchan MR. 2010. Activation of the MCM2-7 helicase by association with Cdc45 and GINS proteins. Mol Cell 37: 247-258.

Ivanov D, Schleiffer A, Eisenhaber F, Mechtler K, Haering C, Nasmyth K. 2002. Ecol is a novel acetyltransferase that can acetylate proteins involved in cohesion. Curr Biol 12: 323-328.

Katou Y, Kanoh Y, Bando M, Noguchi H, Tanaka H, Ashikari T, Sugimoto K, Shirahige K. 2003. S-phase checkpoint proteins Tof1 and Mrc1 form a stable replication-pausing complex. Nature 424: 1078-1083.

Kawauchi S, Calof AL, Santos R, Lopez-Burks ME, Young CM, Hoang MP, Chua A, Lao T, Lechner MS, Daniel JA, et al. 2009. Multiple organ system defects and transcriptional dysregulation in the $\mathrm{Nipbl}^{+/-}$mouse, a model of Cornelia de Lange Syndrome. PLoS Genet 5: e1000650. doi: 10.1371/ journal.pgen.1000650.

Kops GJ, Weaver BA, Cleveland DW. 2005. On the road to cancer: Aneuploidy and the mitotic checkpoint. Nat Rev Cancer 5: 773-785.
Kueng S, Hegemann B, Peters BH, Lipp JJ, Schleiffer A, Mechtler K, Peters J-M. 2006. Wapl controls the dynamic association of cohesin with chromatin. Cell 127: 955-967.

Lee J, Kumagai A, Dunphy WG. 2003. Claspin, a Chk1-regulatory protein, monitors DNA replication on chromatin independently of RPA, ATR, and Rad17. Mol Cell 11: 329340.

Leman AR, Noguchi C, Lee CY, Noguchi E. 2010. Human Timeless and Tipin stabilize replication forks and facilitate sister-chromatid cohesion. J Cell Sci 123: 660-670.

Lengronne A, Katou Y, Mori S, Yokobayashi S, Kelly GP, Itoh T, Watanabe Y, Shirahige K, Uhlmann F. 2004. Cohesin relocation from sites of chromosomal loading to places of convergent transcription. Nature 430: 573-578.

Lengronne A, McIntyre J, Katou Y, Kanoh Y, Hopfner KP, Shirahige K, Uhlmann F. 2006. Establishment of sister chromatid cohesion at the $S$. cerevisiae replication fork. Mol Cell 23: 787-799.

Lindroos HB, Strom L, Itoh T, Katou Y, Shirahige K, Sjogren C. 2006. Chromosomal association of the Smc5/6 complex reveals that it functions in differently regulated pathways. Mol Cell 22: 755-767.

Liu J, Krantz ID. 2008. Cohesin and human disease. Annu Rev Genomics Hum Genet 9: 303-320.

Liu J, Zhang Z, Bando M, Itoh T, Deardorff MA, Clark D, Kaur M, Tandy S, Kondoh T, Rappaport E, et al. 2009. Transcriptional dysregulation in NIPBL and cohesin mutant human cells. PLOS Biol 7: e1000119. doi: 10.1371/journal.pbio. 1000119.

Losada A, Yokochi T, Kobayashi R, Hirano T. 2000. Identification and characterization of SA/Scc3p subunits in the Xenopus and human cohesin complexes. J Cell Biol 150: 405-416.

Losada A, Yokochi T, Hirano T. 2005. Functional contribution of Pds5 to cohesin-mediated cohesion in human cells and Xenopus egg extracts. J Cell Sci 118: 2133-2141.

Lou H, Komata M, Katou Y, Guan Z, Reis CC, Budd M, Shirahige K, Campbell JL. 2008. Mrc1 and DNA polymerase $\epsilon$ function together in linking DNA replication and the $S$ phase checkpoint. Mol Cell 32: 106-117.

MacAlpine HK, Gordan R, Powell SK, Hartemink AJ, MacAlpine DM. 2010. Drosophila ORC localizes to open chromatin and marks sites of cohesin complex loading. Genome Res 20: 201-211.

Masai $\mathrm{H}$, Taniyama C, Ogino $\mathrm{K}$, Matsui E, Kakusho N, Matsumoto S, Kim JM, Ishii A, Tanaka T, Kobayashi T, et al. 2006. Phosphorylation of MCM4 by Cdc7 kinase facilitates its interaction with Cdc45 on the chromatin. J Biol Chem 281: 39249-39261.

McInerney P, Johnson A, Katz F, O’Donnell M. 2007. Characterization of a triple DNA polymerase replisome. Mol Cell 27: 527-538.

Mc Intyre J, Muller EG, Weitzer S, Snydsman BE, Davis TN, Uhlmann F. 2007. In vivo analysis of cohesin architecture using FRET in the budding yeast Saccharomyces cerevisiae. EMBO I 26: 3783-3793.

Michaelis C, Ciosk R, Nasmyth K. 1997. Cohesins: Chromosomal proteins that prevent premature separation of sister chromatids. Cell 91: 35-45.

Milutinovich M, Unal E, Ward C, Skibbens RV, Koshland D. 2007. A multi-step pathway for the establishment of sister chromatid cohesion. PLoS Genet 3: e12. doi: 10.1371/journal. pgen.0030012.

Mishiro $\mathrm{T}$, Ishihara $\mathrm{K}$, Hino $\mathrm{S}$, Tsutsumi $\mathrm{S}$, Aburatani $\mathrm{H}$, Shirahige K, Kinoshita Y, Nakao M. 2009. Architectural roles of multiple chromatin insulators at the human apolipoprotein gene cluster. EMBO I 28: 1234-1245. 
Moldovan GL, Pfander B, Jentsch S. 2006. PCNA controls establishment of sister chromatid cohesion during $\mathrm{S}$ phase. Mol Cell 23: 723-732.

Moldovan GL, Pfander B, Jentsch S. 2007. PCNA, the maestro of the replication fork. Cell 129: 665-679.

Moyer SE, Lewis PW, Botchan MR. 2006. Isolation of the Cdc45/ Mcm2-7/GINS (CMG) complex, a candidate for the eukaryotic DNA replication fork helicase. Proc Natl Acad Sci 103: 10236-10241.

Nasmyth K, Haering CH. 2009. Cohesin: Its roles and mechanisms. Annu Rev Genet 43: 525-558.

Nativio R, Wendt KS, Ito Y, Huddleston JE, Uribe-Lewis S, Woodfine K, Krueger C, Reik W, Peters JM, Murrell A. 2009. Cohesin is required for higher-order chromatin conformation at the imprinted IGF2-H19 locus. PLoS Genet 5: e1000739. doi: 10.1371/journal.pgen.1000739.

Neuwald AF, Hirano T. 2000. HEAT repeats associated with condensins, cohesins, and other complexes involved in chromosome-related functions. Genome Res 10: 1445-1452.

Pacek M, Tutter AV, Kubota Y, Takisawa H, Walter JC. 2006. Localization of MCM2-7, Cdc45, and GINS to the site of DNA unwinding during eukaryotic DNA replication. Mol Cell 21: 581-587.

Panizza S, Tanaka T, Hochwagen A, Eisenhaber F, Nasmyth K. 2000. Pds5 cooperates with cohesin in maintaining sister chromatid cohesion. Curr Biol 10: 1557-1564.

Parelho V, Hadjur S, Spivakov M, Leleu M, Sauer S, Gregson HC, Jarmuz A, Canzonetta C, Webster Z, Nesterova T, et al. 2008. Cohesins functionally associate with CTCF on mammalian chromosome arms. Cell 132: 422-433.

Pauli A, Althoff F, Oliveira RA, Heidmann S, Schuldiner O, Lehner CF, Dickson BJ, Nasmyth K. 2008. Cell-type-specific TEV protease cleavage reveals cohesin functions in Drosophila neurons. Dev Cell 14: 239-251.

Petermann E, Helleday T, Caldecott KW. 2008. Claspin promotes normal replication fork rates in human cells. Mol Biol Cell 19: 2373-2378.

Petronczki M, Chwalla B, Siomos MF, Yokobayashi S, Helmhart W, Deutschbauer AM, Davis RW, Watanabe Y, Nasmyth K. 2004. Sister-chromatid cohesion mediated by the alternative RF-CCtf18/Dcc1/Ctf8, the helicase Chl1 and the polymerase$\alpha$-associated protein Ctf4 is essential for chromatid disjunction during meiosis II. J Cell Sci 117: 3547-3559.

Randell JC, Bowers JL, Rodriguez HK, Bell SP. 2006. Sequential ATP hydrolysis by Cde6 and ORC directs loading of the Mcm2-7 helicase. Mol Cell 21: 29-39.

Rankin S, Ayad NG, Kirschner MW. 2005. Sororin, a substrate of the anaphase-promoting complex, is required for sister chromatid cohesion in vertebrates. Mol Cell 18: 185-200.

Remus D, Beuron F, Tolun G, Griffith JD, Morris EP, Diffley JF. 2009. Concerted loading of $\mathrm{Mcm} 2-7$ double hexamers around DNA during DNA replication origin licensing. Cell 139: 719-730.

Reyes-Lamothe R, Sherratt DI, Leake MC. 2010. Stoichiometry and architecture of active DNA replication machinery in Escherichia coli. Science 328: 498-501.

Rolef Ben-Shahar T, Heeger S, Lehane C, East P, Flynn H, Skehel M, Uhlmann F. 2008. Ecol-dependent cohesin acetylation during establishment of sister chromatid cohesion. Science 321: 563-566.

Rollins RA, Morcillo P, Dorsett D. 1999. Nipped-B, a Drosophila homologue of chromosomal adherins, participates in activation by remote enhancers in the cut and Ultrabithorax genes. Genetics 152: 577-593.

Rollins RA, Korom M, Aulner N, Martens A, Dorsett D. 2004. Drosophila nipped-B protein supports sister chromatid co- hesion and opposes the stromalin/Scc3 cohesion factor to facilitate long-range activation of the cut gene. Mol Cell Biol 24: 3100-3111.

Rowland BD, Roig MB, Nishino T, Kurze A, Uluocak P, Mishra A, Beckouet F, Underwood P, Metson J, Imre R, et al. 2009. Building sister chromatid cohesion: smc3 acetylation counteracts an antiestablishment activity. Mol Cell 33: 763774.

Rubio ED, Reiss DJ, Welcsh PL, Disteche CM, Filippova GN, Baliga NS, Aebersold R, Ranish JA, Krumm A. 2008. CTCF physically links cohesin to chromatin. Proc Natl Acad Sci 105: 8309-8314.

Sakai A, Hizume K, Sutani T, Takeyasu K, Yanagida M. 2003. Condensin but not cohesin SMC heterodimer induces DNA reannealing through protein-protein assembly. $E M B O I$ 22: 2764-2775.

Schmitz J, Watrin E, Lénárt P, Mechtler K, Peters J-M. 2007. Sororin is required for stable binding of cohesin to chromatin and for sister chromatid cohesion in interphase. Curr Biol 17: 630-636.

Schuldiner O, Berdnik D, Levy JM, Wu JS, Luginbuhl D, Gontang AC, Luo L. 2008. piggyBac-based mosaic screen identifies a postmitotic function for cohesin in regulating developmental axon pruning. Dev Cell 14: 227-238.

Seitan VC, Banks P, Laval S, Majid NA, Dorsett D, Rana A, Smith J, Bateman A, Krpic S, Hostert A, et al. 2006. Metazoan Scc4 homologs link sister chromatid cohesion to cell and axon migration guidance. PLoS Biol 4: e242. doi: 10.1371/journal. pbio.0040242.

Sheu YJ, Stillman B. 2006. Cdc7-Dbf4 phosphorylates MCM proteins via a docking site-mediated mechanism to promote S phase progression. Mol Cell 24: 101-113.

Shintomi K, Hirano T. 2009. Releasing cohesin from chromosome arms in early mitosis: Opposing actions of Wapl-Pds5 and Sgol. Genes Dev 23: 2224-2236.

Skibbens RV, Corson LB, Koshland D, Hieter P. 1999. Ctf7p is essential for sister chromatid cohesion and links mitotic chromosome structure to the DNA replication machinery. Genes Dev 13: 307-319.

Stead K, Aguilar C, Hartman T, Drexel M, Meluh P, Guacci V. 2003. Pds5p regulates the maintenance of sister chromatid cohesion and is sumoylated to promote the dissolution of cohesion. J Cell Biol 163: 729-741.

Stedman W, Kang H, Lin S, Kissil JL, Bartolomei MS, Lieberman PM. 2008. Cohesins localize with CTCF at the KSHV latency control region and at cellular c-myc and H19/Igf2 insulators. EMBO I 27: 654-666.

Stillman B. 2008. DNA polymerases at the replication fork in eukaryotes. Mol Cell 30: 259-260.

Sumara I, Vorlaufer E, Gieffers C, Peters B, Peters J. 2000. Characterization of vertebrate cohesin complexes and their regulation in prophase. J Cell Biol 151: 749-762.

Sutani T, Kawaguchi T, Kanno R, Itoh T, Shirahige K. 2009. Budding yeast Wpl1(Rad61)-Pds5 complex counteracts sister chromatid cohesion-establishing reaction. Curr Biol 19: 492497.

Szyjka SJ, Viggiani CJ, Aparicio OM. 2005. Mrc1 is required for normal progression of replication forks throughout chromatin in S. cerevisiae. Mol Cell 19: 691-697.

Takahashi TS, Yiu P, Chou MF, Gygi S, Walter JC. 2004. Recruitment of Xenopus Scc2 and cohesin to chromatin requires the pre-replication complex. Nat Cell Biol 6: 991996.

Takahashi TS, Basu A, Bermudez V, Hurwitz J, Walter JC. 2008. Cdc7-Drf1 kinase links chromosome cohesion to the 
initiation of DNA replication in Xenopus egg extracts. Genes Dev 22: 1894-1905.

Tanaka K, Yonekawa T, Kawasaki Y, Kai M, Furuya K, Iwasaki M, Murakami H, Yanagida M, Okayama H. 2000. Fission yeast Esolp is required for establishing sister chromatid cohesion during S phase. Mol Cell Biol 20: 3459-3469.

Tanaka K, Hao Z, Kai M, Okayama H. 2001. Establishment and maintenance of sister chromatid cohesion in fission yeast by a unique mechanism. EMBO I 20: 5779-5790.

Tanaka H, Katou Y, Yagura M, Saitoh K, Itoh T, Araki H, Bando M, Shirahige K. 2009. Ctf4 coordinates the progression of helicase and DNA polymerase $\alpha$. Genes Cells 14: 807820.

Terret M-E, Sherwood R, Rahman S, Qin J, Jallepalli PV. 2009. Cohesin acetylation speeds the replication fork. Nature 462: 231-234.

Tomonaga T, Nagao K, Kawasaki Y, Furuya K, Murakami A, Morishita J, Yuasa T, Sutani T, Kearsey SE, Uhlmann F, et al. 2000. Characterization of fission yeast cohesin: Essential anaphase proteolysis of Rad21 phosphorylated in the S phase. Genes Dev 14: 2757-2770.

Toth A, Ciosk R, Uhlmann F, Galova M, Schleiffer A, Nasmyth K. 1999. Yeast cohesin complex requires a conserved protein, Ecolp(Ctf7), to establish cohesion between sister chromatids during DNA replication. Genes Dev 13: 320-333.

Tourriere H, Versini G, Cordon-Preciado V, Alabert C, Pasero P. 2005. Mrc1 and Tof 1 promote replication fork progression and recovery independently of Rad53. Mol Cell 19: 699-706.

Uhlmann F, Nasmyth K. 1998. Cohesion between sister chromatids must be established during DNA replication. Curr Biol 8: 1095-1101.

Unal E, Heidinger-Pauli JM, Kim W, Guacci V, Onn I, Gygi SP, Koshland DE. 2008. A molecular determinant for the establishment of sister chromatid cohesion. Science 321: 566-569.

Unsal-Kacmaz K, Chastain PD, Qu PP, Minoo P, Cordeiro-Stone M, Sancar A, Kaufmann WK. 2007. The human Tim/Tipin complex coordinates an intra-S checkpoint response to UV that slows replication fork displacement. Mol Cell Biol 27: 3131-3142.

van der Lelij P, Godthelp BC, van Zon W, van Gosliga D, Oostra $A B$, Steltenpool J, de Groot J, Scheper RJ, Wolthuis RM, Waisfisz Q, et al. 2009. The cellular phenotype of Roberts syndrome fibroblasts as revealed by ectopic expression of ESCO2. PLOS ONE 4: e6936. doi: 10.1371/journal.pone. 0006936.

van der Lelij P, Chrzanowska KH, Godthelp BC, Rooimans MA, Oostra AB, Stumm M, Zdzienicka MZ, Joenje $H$, de Winter JP. 2010. Warsaw breakage syndrome, a cohesinopathy associated with mutations in the XPD helicase family member DDX11/ChlR1. Am J Hum Genet 86: 262-266.

Vega H, Waisfisz Q, Gordillo M, Sakai N, Yanagihara I, Yamada M, van Gosliga D, Kayserili H, Xu C, Ozono K, et al. 2005. Roberts syndrome is caused by mutations in $\mathrm{ESCO} 2$, a human homolog of yeast ECO1 that is essential for the establishment of sister chromatid cohesion. Nat Genet 37: 468-470.

Vernì F, Gandhi R, Goldberg ML, Gatti M. 2000. Genetic and molecular analysis of wings apart-like (wapl), a gene controlling heterochromatin organization in Drosophila melanogaster. Genetics 154: 1693-1710.

Watrin E, Schleiffer A, Tanaka K, Eisenhaber F, Nasmyth K, Peters JM. 2006. Human Scc4 is required for cohesin binding to chromatin, sister-chromatid cohesion, and mitotic progression. Curr Biol 16: 863-874.

Weitzer S, Lehane C, Uhlmann F. 2003. A model for ATP hydrolysis-dependent binding of cohesin to DNA. Curr Biol 13: $1930-1940$.
Wendt $\mathrm{K}$, Yoshida $\mathrm{K}$, Itoh T, Bando $\mathrm{M}$, Koch B, Schirghuber E, Tsutsumi S, Nagae G, Ishihara K, Mishiro T, et al. 2008. Cohesin mediates transcriptional insulation by CCCTCbinding factor. Nature 451: 796-801.

Williams BC, Garrett-Engele CM, Li Z, Williams EV, Rosenman ED, Goldberg ML. 2003. Two putative acetyltransferases, san and deco, are required for establishing sister chromatid cohesion in Drosophila. Curr Biol 13: 2025-2036.

Woese CR, Kandler O, Wheelis ML. 1990. Towards a natural system of organisms: Proposal for the domains archaea, bacteria, and eucarya. Proc Natl Acad Sci 87: 4576-4579.

Yoshizawa-Sugata N, Masai H. 2007. Human Tim/Timelessinteracting protein, Tipin, is required for efficient progression of S phase and DNA replication checkpoint. J Biol Chem 282: $2729-2740$.

Zhang J, Shi X, Li Y, Kim BJ, Jia J, Huang Z, Yang T, Fu X, Jung SY, Wang Y, et al. 2008. Acetylation of Smc3 by Ecol is required for $S$ phase sister chromatid cohesion in both human and yeast. Mol Cell 31: 143-151.

Zhang B, Chang J, Fu M, Huang J, Kashyap R, Salavaggione E, Jain S, Kulkarni S, Deardorff MA, Uzielli ML, et al. 2009. Dosage effects of cohesin regulatory factor PDS5 on mammalian development: Implications for cohesinopathies. PLOS ONE 4: e5232. doi: 10.1371/journal.pone.0005232.

Zhu W, Ukomadu C, Jha S, Senga T, Dhar SK, Wohlschlegel JA, Nutt LK, Kornbluth S, Dutta A. 2007. Mcm10 and And-1/ CTF4 recruit DNA polymerase $\alpha$ to chromatin for initiation of DNA replication. Genes Dev 21: 2288-2299. 


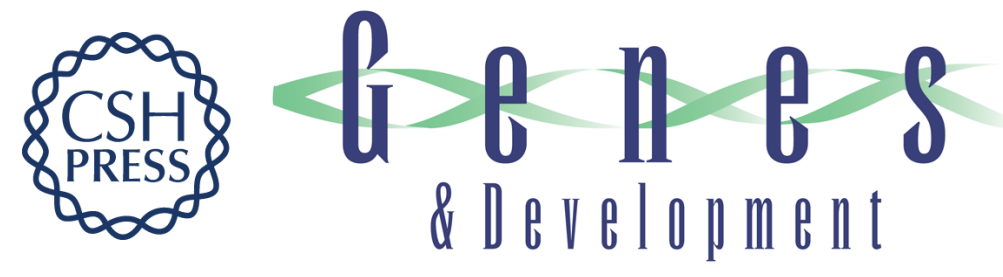

\section{Sister acts: coordinating DNA replication and cohesion establishment}

Rebecca Sherwood, Tatsuro S. Takahashi and Prasad V. Jallepalli

Genes Dev. 2010, 24:

Access the most recent version at doi:10.1101/gad.1976710

References This article cites 125 articles, 44 of which can be accessed free at: http://genesdev.cshlp.org/content/24/24/2723.full.html\#ref-list-1

License

Email Alerting Receive free email alerts when new articles cite this article - sign up in the box at the top Service right corner of the article or click here.

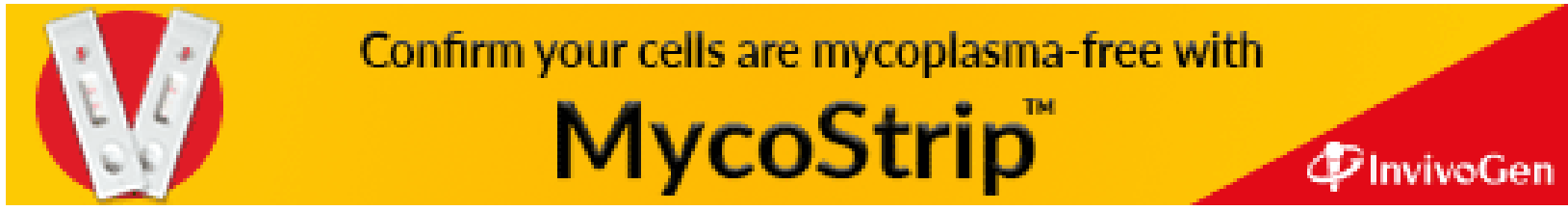

